\title{
MEMBANGUN BAHASA KOMUNIKATIF UNTUK ANAK USIA DINI
}

\author{
Rina Devianty, S.S.,M.Pd. \\ Dosen di Universitas Islam Negeri Sumatera Utara Medan \\ Email: rinadevianty@uinsu.ac.id
}

\begin{abstract}
Language is the most effective communication tool in social interaction. When communicating, communicative language skills are certainly needed by anyone, including children and parents. Parents have a very important role to play in improving communicative language mastery for early childhood. By using communicative language, it is expected to have a positive impact on children's language development. So, children are not only passive language users, but also become active language users.
\end{abstract}

Keywords: language, communicative, early childhood

\begin{abstract}
Abstrak: Bahasa merupakan alat komunikasi yang paling efektif dalam berinteraksi sosial. Saat berkomunikasi, kemampuan berbahasa yang komunikatif tentu sangat diperlukan oleh siapa saja, termasuk anak-anak dan orang tua. Orang tua memiliki peran yang sangat penting untuk meningkatkan penguasaan bahasa yang komunikatif untuk anakusia dini. Dengan menggunakan bahasa yang komunikatif, diharapkan akan membawa dampak yang positif terhadap perkembangan bahasa anak. Jadi, anak-anak tidak hanya sebagai pengguna bahasa yang pasif, tetapi juga menjadi pengguna bahasa yang aktif.
\end{abstract}

Kata kunci: bahasa, komunikatif, anak usia dini

\section{A. Pendahuluan}

Keterampilan berbahasa anak tidak diperoleh secara otomatis atau diperoleh begitu saja, tetapi ada usaha yang dilakukan guru dan orang tua untuk memperoleh keterampilan bahasa tersebut. Salah satu yang mempengaruhi kemampuan berbahasa anak adalah lingkungan. Semakin besar pengaruh yang diberikan lingkungan tehadap bahasa, semakin besar pula kontribusinya bagi peningkatan keterampilan anak dalam berbahasa. Dari pernyataan tersebut dapat disimpulkan bahwa perkembangan keterampilan berbahasa sangat dipengaruhi oleh sikap dan perilaku lingkungannya. Oleh karena itu, orang tua sebagai lingkungan yang pertama dan utama bagi kehidupan manusia sangat menentukan tingkat kemampuan berbahasa anak. 
Pengaruh orang tua terhadap kemampuan berbahasa anakmemang tidak diragukan lagi. Namun, masih banyak orang beranggapan bahwa keterampilan bahasa anak akan berkembang dengan sendirinya selaras dengan perkembangan jasmani dan bertambahnya usia anak. Anggapan ini tentu saja merupakan anggapan yang keliru karena lingkungan terdekat anak, terutama keluarga sangat berperan dalam perkembangan keterampilan bahasa anak

Sekarang ini, masih banyak orang tua yang masih belum berusaha untuk melatih dan mengembangkan keterampilan berbahasa. Padahal, keterampilan berbahasa sangat dibutuhkan oleh manusia untuk bersosialisasi dengan orang lain karena manusia adalah makhluk sosial. Manusia selalu membutuhkan orang lain untuk menyampaikan keinginan, ide-ide, serta pendapatnya dalam memenuhi kebutuhan hidupnya. Oleh karena itu, keterampilan berbahasa sangat penting bagi kehidupan manusia.

Gejala-gejala kurangnya keterampilan berbahasa, khususnya berbahasa Indonesia dapat dilihat sejak dari usia sekolah sampai ke perguruan tinggi. Hanya sedikit anak atau peserta didik yang mau bertanya di dalam proses pembelajaran meskipun guru atau dosen telah menggunakan metode atau pendekatan tanya jawab atau diskusi yang tujuannya untuk meningkatkan ketrampilan anak atau peserta didik dalam berkomunikasi. Jadi, perlu adanya usaha lain agar dapat membangun bahasa yang komunikatif untuk anak usia dini.

\section{B. Bahasa Komunikatif}

Bahasa memiliki peran penting dalam kehidupan manusia karena bahasa merupakan sarana yang digunakan manusia untuk berkomunikasi dan mengekspresikan keinginannya sebagai makhluk sosial. Dalam Kamus Besar Bahasa Indonesia (KBBI) edisi IV (2004: 116),dituliskan bahwa:

1. bahasa merupakan sistem lambang bunyi yang arbitrer, yang digunakan oleh anggota masyarakat untuk bekerja sama, berinteraksi, dan mengidentifikasikan diri.

2. bahasa merupakan percakapan (perkataan) yang baik, sopan santun. 
Menurut Keraf (1980: 3), bahasa bila ditinjau dari dasar dan motif pertumbuhannya, berfungsi sebagai:

1. alat untuk menyatakan ekspresi diri

2. alat komunikasi

3. alat untuk mengadakan integrasi dan adaptasi sosial

4. alat untuk mengadakan kontrol sosial.

Empat fungsi bahasa yang diungkapkan Keraf tersebut salah satunya menunjukkan cara yang bisa dikategorikan sebagai lingkungan pendidikan, yakni masyarakat.

Dari uraian tentang bahasa tersebut, bisa dilihat bahwa bahasa adalah hal yang sangat vital untuk dikuasai. Bahasa bukan hanya sebagai alat komunikasi, melainkan memiliki fungsi lain, salah satunya adalah sebagai alat kontrol sosial. Sebagai alat kontrol sosial, bahasa menjadi tolak ukur atau penilaian terhadap perilaku atau karakter seseorang. Karakter seseorang bisa dinilai, salah satunya melalui komunikasi. Orang yang bisa berkomunikasi dengan baik dan bertutur kata dengan sopan tentu memiliki karakter atau perilaku yang baik pula. Demikian pula sebaliknya, orang yang tidak bisa berkomunikasi dengan baik dan tidak dapat bertutur kata sopan tentu memiliki karakter yang tidak baik pula.

Pengertian komunikatif dalam Kamus Besar Bahasa Indonesia edisi $I V(2004:$ 517) adalah mudah dipahami (dimengerti). Komunikatif artinya mampu menyampaikan pesan dengan baik, artinya pesan yang diterima oleh penerima (receiver) sama dengan maksud pesan yang disampaikan oleh pengirim pesan (sender). Yang dimaksud dengan pesan di sini bukan hanya informasi, melainkan juga pemikiran, keinginan, dan perasaan. Jadi, bahasa komunikatif adalah bahasa yang mudah dipahami sehingga pesan yang disampaikan oleh si pembicara bisa dengan mudah dimengerti oleh si pendengar.

Bahasa yang komunikatif perlu dipelajari sejak usia dini karena bahasa merupakan alat berkomunikasi yang digunakan untuk berinterakasi dan bersosialisasi. Jika anak terbiasa dengan menggunakan bahasa yang komunikatif saat dia berinteraksi, tentu apa yang menjadi pemikiran, keinginan, ataupun perasaannya akan bisa tersalurkan dengan tepat. 


\section{Perkembangan Bahasa terhadap Anak}

Kemampuan atau keterampilan berbicara adalah kemampuan mengungkapkan gagasan, pendapat dan perasaan pada pihak lain secara lisan. Ketepatan mengungkapkan gagasan pendapat dan perasaan dipengaruhi oleh penggunaan bahasa yang efektif, tepat, dan sesuai dengan kaidah ketatabahasaanyang berlaku. Agar dapat terjadi hubungan komunikasi timbal balik yang sesuai dengan tujuan komunikasi, segala hal yang berkaitan dengan proses komunikasi harus diperhatikan. Unsur utama dalam komunikasi adalah bagaimana seseorang dapat menggunakan bahasa atau diksi yang baik dan tepat. Selain itu, perlu dipertimbangkan pula aspek situasi, waktu, tempat, dan hubungan pembicara mitra atau lawan bicaranya. Misalnya, saat membuka percakapan, saat menyampaikan pesan, dan ketika akan menutup pembicaraan. Hal-hal tersebut biasanya memengaruhi pilihan kata danungkapan yang digunakan dalam percakapan.

\section{Kemampuan Berbahasa Anak}

Bahasa merupakan rangkaian bunyi yang melambangkan pikiran, perasaan serta sikap manusia. Sedangkan pengertian bahasa anak menurut Suhartono (2005: 8), yaitu bahasa yang dipakai oleh anak untuk menyampaikan keinginan pikiran, harapan permintaan dan lain-lain untuk kepentingan pribadinya. Dalam berkomunikasi, kita menggunakan kemampuan berbahasa yang telah ada dalam bertingkah laku. Kualitas kemampuan berbahasa yang dimiliki oleh setiap orang berbeda-beda. Ada yang sangat optimal dan ada yang sangat lemah dalam kemampuan berbahasanya sehingga tujuan dalam hasil berkomunikasi dengan orang lain berbeda (Depdiknas, 2004:4).

Dalam kehidupan sehari-hari, manusia menggunakan bahasa untuk berbicara, berpikir, menyimak, dan berkomunikasi dengan orang lain. Namun, dalam menggunakan kemampuanberbahasa bukanlah kemampuan yang bersifat alamiah, seperti bernafas dan berjalan. Kemampuan berbahasa tidak dibawa sejak 
lahir dan dikuasai dengan sendirinya, tetapi harus dipelajari. Kemampuan berbahasa yang dimiliki anak merupakan langkah awal dalam memahami perkembangan bahasa anak secara individual, termasuk di dalamnya mendeteksi kemampuan membaca dan menulis. Anak harusnya mampu menggunakan bahasa untuk pemahaman bahasa pasif dan dapat berkomunikasi secara efektif yang bermanfaat untuk berpikir dan belajar.

Salah satu bentuk pembelajaran terhadap anak adalah peningkatan kemampuan berbahasa. Peningkatan ini merupakan bagian dari kemampuan dasar yang bertujuan agar anak mampu mendengarkan, berkomunikasi secara lisan, memiliki perbendaharaan kata, dan mengenal simbol-simbol yang melambangkannya (Depdiknas, 2004: 7). Adapun hasil yang ingin dicapai adalah agar anak dapat mendengarkan dan memahami kata serta kalimat sederhana serta mengenal bahwa ada hubungan antara bahasa lisan dan tulisan.

Dari uraian di atas, jelaslah bahwa kemampuan berbahasa merupakan kemampuan yang bukan bersifat alamiah, melainkan harus dipelajari. Anak mampu menggunakan bahasa untuk pemahaman bahasa pasif dan dapat mengomunikasikannya secara efektif sehingga dapat bermanfaat untuk berpikir dan belajar. Kemampuan berbahasa merupakan bagian dari kemampuan dasar yang bertujuan agar anak mampu mendengarkan, mengomunikasikan secara lisan, memiliki perbendaharaan kata, dan mengenal simbol-simbol yang melambangkannya.

\section{Faktor-Faktor Pendukung Perkembangan Berbahasa Anak}

Faktor pendukung adalah segala sesuatu yang dapat mendorong atau mempengaruhi siswa dalam meningkatkan kemampuan pembelajarannya untuk menjadi lebih baik. Adapun faktor-faktor pendukung kemampuan tersebut adalah sebagai berikut:

\section{a) Faktor internal.}

Faktor internal, yaitu faktor yang berasal dari dalam diri siswa, baik kondisi jasmani atau fisiologis maupun rohani atau psikologis (Muhibbin Syah, 2003: 147-148). Faktor fisiologis yaitu kondisi umum jasmani dan tonus 


\section{NIZHAMIYAH}

Vol. IX No. 2, Juli - Desember 2019

(tegangan otot)yang menandai tingkat kebugaran organ-organ tubuh dan sendisendinya dapat mempengaruhi semangat dan intensitas siswa dalam mengikuti pelajaran. Kondisi tubuh yang lemah, apalagi disertai dengan pusing kepala, misalnya dapat menurunkan kualitas ranah cipta (kognitif) sehingga materi yang dipelajarinya pun kurang atau tidak berbekas. Selain itu, hal yang tidak kalah pentingnya adalah kondisi pancaindra (mata, hidung, pengecap, telinga, dan tubuh) karena sebagian besar serangkaian dari proses belajar menggunakan pancaindra tersebut.

Faktor psikologis sebagai faktor dari dalam tentu saja merupakan hal yang utama dalam intensitas pembelajaran. Adapun faktor- faktor psikologis ini antara lain:

1. Minat

Minat berarti kecenderungan dan kegairahan yang tinggi atau keinginan yang besar terhadap sesuatu. Suatu minat dapat diekspresikan melalui suatu pernyatan yang menunjukkan bahwa anak didik lebih menyukai suatu hal lainnya, dapat pula dimanifestasikan melalui partisipasi dalam suatu aktivitas. Anak didik mempunyai minat terhadap subyek tertentu, cenderung untuk memberikan perhatian yang lebih besar terhadap subyek tersebut. Minat yang besar terhadap sesuatu merupakan modal yang besar, artinya untuk mencapai atau memperoleh benda atau tujuan yang diminati itu. Timbulnya minat belajar disebabkan berbagai hal, antara lain keinginan yang kuat untuk menaikkan martabat atau memperoleh pekerjaan yang baikserta ingin hidup senang dan bahagia. Minat belajar yang besar cenderung menghasilkan prestasi yang tinggi, sebaliknya minat belajar kurang akan menghasilkan prestasi yang rendah.

2. Intelegensi.

Intelelegensi pada umumnya dapat diartikan sebagai kemampuan psikofisik untuk mereaksi rangsangan atau menyesuaikan diri dengan lingkungan dengan cara yang tepat. Pada dasarnya, intelegensi sebenarnya bukan kemampuan otak saja melainkan kualitas organ-organ tubuh lainnya. Akan tetapi,memang harus diakui bahwa peran otak dalam hubungannya dengan inteligensi lebih 
menonjol dari pada peran organ-organ tubuh lainnya karena otak merupakan pengontrol hampir seluruh aktivitas manusia.

\section{Bakat}

Secara umum, bakat adalah kemampuan potensial yang dimiliki seseorang untuk mencapai keberhasilan pada masa yang akan datang. Dengan demikian, sebetulnya setiap orang memiliki bakat dan berpotensi untuk mencapai prestasi sampai ketingkat tertentu sesuai dengan kapasitas masing-masing. Jadi, secara global bakat itu mirip dengan intelegensi. Itulah sebabnya seorang anak yang berintelegensi tinggi disebut juga sebagai anak berbakat.Motivasi berhubungan dengan kebutuhan, motif, dan tujuan. Hal ini sangat mempengaruhi dalam proses pembelajaran.

\section{Motivasi}

Motivasi penting bagi proses belajar karena motivasi menggerakkan organisme, mengarahkan tindakan, serta memilih tujuan. Motivasidapat dibedakan menjadi dua macam, yaitu, (1) motivasi intrinsik, (2) motivasi ekstrinsik. Motivasi intrinsik adalah hal dan keadaan yang berasal dari dalam diri siswa sendiri yang dapat mendorongnya melakukan tindakan belajar. Misalnya, perasaan siswa yang menyenangi materi dan kebutuhan terhadap materi tersebut. Adapun motivasi ekstrinsik adalah hal dan keadaan yang datang dari luar individu siswa yang juga mendorongnya untuk melakukan kegiatan belajar.

\section{Kemampuan kognitif.}

Dalam dunia pendidikan, dikenal tiga tujuan pendidikan, yaitu ranah kognitif, ranah afektif, dan ranah psikomotorik. Dari ketiga ranah tersebut, ranah kognitif merupakan kemampuan yang selalu dituntut untuk dikuasai anak didik karena penguasaan kemampuan pada tingkatan itu menjadi dasar bagi penguasaan ilmu pengetahuan.

\section{b) Faktor eksternal}

Selain dari faktor internal, pembelajaran juga dipengaruhi oleh faktor eksternal, yaitu faktor yang berasal dari luar diri siswa. Faktor eksternal ini dibagi menjadi dua, yaitu (1) lingkungan yakni yang berasal dari alam maupun sosial 
budaya, dan (2) instrumental, yakni fasilitas serta media yang disediakan di sekolah.

1. Lingkungan.

Ada dua jenis lingkungan, yaitu:

a. Lingkungan alami, yaitu lingkungan merupakan bagian dari kehidupan anak didik, tempat mereka hidup dan berusaha di dalamnya. Pencemaran lingkungan hidup merupakan malapetaka bagi anak didik yang hidup di dalamnya karena membuat suasana menjadi tidak nyaman sehingga dapat mengganggu proses pembelajaran.

b. Lingkungan sosial budaya, yaitu manusia sebagaimakhluk sosial yang berkecenderungan untuk hidup bersama satu dengan lainnya. Sebagai anggota masyarakat, anak didik tidak bisa melepaskan diri dari ikatan sosial. Lingkungan sosial budaya di luar sekolah ternyata sisi kehidupan yang mendatangkan problem tersendiri bagi kehidupan anak didik di sekolah. Mengingat pengaruh yang kurang menguntungkan dari lingkungan pabrik, pasar, dan arus lalu lintas, alangkah baiknya jika pembangunan gedung sekolah ditempat yang jauh dari lingkungan ramai. Keluarga juga memiliki pengaruh yang sangat besar dalam proses pembelajaran, terutama orang tua. Tinggi rendahnya pendidikan, besar kecilnya penghasilan, cukup atau kurangnya bimbingan dan perhatian orang tua, semua itu mempengaruhi pencapaian hasil belajar anak didik.

2. Instrumental

Setiap sekolah mempunyai tujuan yang akan dicapai. Untuk mencapai tujuan tersebut diperlukan seperangkat kelengkapan dalam berbagai bentuk dan jenisnya. Semuanya dapat dibedakan menurut fungsi masing-masing kelengkapan sekolah. Faktor instrumental yang ada dalam sekolah, diantaranya adalah kurikulum, program sekolah, sarana dan fasilitas sekolah. Guru merupakan unsur manusiawi dalam pendidikan. Kehadiran guru mutlak diperlukan di dalamnya. Kalau hanya ada anak 


\section{NIZHAMIYAH}

didik sedangkan guru tidak ada, maka tidak akan terjadi proses pembelajaran di sekolah.

\section{Membangun Bahasa Komunikatif pada Anak Usia Dini}

Perkembangan anak usia dinisangat bergantung pada bagaimana cara orang tua mendidiknya. Salah satu cara mendidik yang baik ialah dengan membangun bahasa komunikatif anak. Orang tua yang mampu membangun bahasa yang komunikatif dengan anaknya, maka akan membawa suasana yang nyaman bagi anaknya juga. Perasaan seperti dilindungi, dihargai dan diperhatikan pun akan muncul seiring dengan membaiknya komunikasi antara orangtua dengan anak. Selain itu, anak-anak yang memiliki komunikasi yang baik dengan orangtuanya mampu berkembang optimal sesuai potensinya. Melalui tanggapantanggapan orang tuanya ketika berkomunikasi, anak dapat belajar mengenai banyak informasi dan pengetahuan. Mendapatkan sesuatu yang berbeda dari apa yang dipikirkannya selama ini. Komunikasi yang efektifsangat baik untuk mengembangkan kematangan emosional anak, kepandaian intelektual, kemampuan dalam kehidupan sosial yang baik, serta dapat menanamkan nilai prinsip moral baik pada anak. (Muhyidin, 2007:53).

Pada zaman sekarang ini, masih ada banyak orangtua yang tidak menyadari betapa pentingnya membangun bahasa yang komunikatif dengan anak. Bahkan lebih mementingkan aktivitasnya masing-masing daripada berkomunikasi dengan anaknya. Padahal, ketika orangtua mampu membangun bahasa yang komunikatif dengan anaknya, maka anak pun akan merasa nyaman. Anak-anak yang memiliki komunikasi baik dengan orangtuanya akanmampu berkembang optimal sesuai dengan potensinya.

Komunikasi tidak terbatas dalam bentuk kata-kata saja, tetapi mencakup ekspresi, seperti bahasa tubuh, senyuman, pelukan, ciuman sayang, dan kata-kata. Hal-hal tersebut merupakan sebuah kesatuan. Selain itu, dengan mau mendengarkan secara totalitas saat berkomunikasi dengan anak, memberikan perhatian, dan memahami emosi serta pikiran orang yang bicara,juga termasuk ke dalam berkomunikasi.Mendengarkan dengan baik cerita anak, baik itu menyenangkan dan 


\section{NIZHAMIYAH}

menyedihkan dapat membuat anak biasa bersikap terbuka pada orangtuanya. Jika anak masih sulit mengidentifikasikan perasaannya, bantulah dengan dengan cara mendengarkan ceritanya sambil bertanya. Anak tentu akan merasa lega ketika orangtua mampu menangkap perasaannya. Ketika orangtua mampu mendengarkan dengan baik cerita anaknya, dari komunikasi tersebut, anak dapat menarikkesimpulan bagaimana orang dewasa memandang dirinya. Kesan inilah yang nantinya membangun kepercayaan diri anak-anak. Melalui tanggapan-tanggapan orangtuanya, anak dapat belajar mengenai banyak informasi dan pengetahuan. Mendapatkan sesuatu yang berbeda dari apa yang dipikirkannya selama ini. Komunikasi efektif baik untuk mengembangkan kematangan emosional anak, kepandaian intelektual, kemampuan dalam kehidupan sosial yang baik serta menanamkan nilai prinsip moral baik pada anak.

Berikut ini adalah beberapa kiat yang bisa dilakukan orang tua maupun guruuntuk membangun bahasa komunikatif dengan anak usia dini.

a. Jangan bicara terlalu cepatkepada anak. Kemampuan anak dalam menangkap atau menyimak pembicaraan masih terbatas, cenderung lebih lama menyerapnya dibandingkan dengan orang dewasa. Jadi, saat berbicara dengan anak sebaiknya perlahan-lahan agar apa yang mau disampaikan bisa dengan mudah dicerna anak.

b. Biasakan untuk membaca bahasa tubuh anak. Perhatikan apakah anak pada saat itu sedang marah, merajuk, senang, dan sebagainya. Dengan memperhatikan bahasa tubuh anak, orang tua akan tahu bagaimana membangun komunikasi yang efektif dengan si anak

c. Hindarilahberbicara dengan nada memerintah, meremehkan, menyalahkan, membandingkan, dan sebagainya kepada anak karena hal-hal tersebut akan membuat anak tertekan dan ini tentu tidak baik bagi perkembangan psikologisnya.

d. Hindari mengajukan pertanyaan yang menghakimi anak. Lebih baik memberikan pertanyaan yang membuat mereka semakin memahami kejadian yang sedang dialaminya.

e. Sebaiknya pada saat orang tua berkomunikasi dengan anak lebih baik banyak mendengarkan daripada berbicara. Jadi anak bisa lebih bebas mengekspresikan perasaannya 
f. Gunakan kalimat yang positif. Hindari menggunakan kata jangan dan tidakboleh dengan maksud melarang anak melakukan tindakan tertentu. Sebaiknya gunakan kalimat dengan kata-kata yang positif, contoh "kamu jangan malas menggosok gigi!" lebih baik kalimatnya diganti dengan kalimat positif, contoh "kalau kamu rajin menggosok gigi, gigi kamu akan sehat dan kuat".

g. Tunjukkan mimik muka dan bahasa tubuh yang positif. Hal tersebut akanmembuat hati anak senang dan nyaman. Contoh: tersenyum saat mereka berbicara, menyentuh, atau mengusap rambut anak, dan sebagainya.

h. Upayakan ada kontak mata dansaling melihat saat berkomunikasi dengan anak agar anak merasa diperhatikan dan anak merasakan bahwa apa yang kita sampaikan merupakan hal yang sungguh-sungguh.

i. Gunakan kalimat sederhana atau mudah dipahami oleh anak.Anak belum memiliki kemampuan mengingat kalimat yang panjang dan bertele-tele. Sebaiknya orangtua berbicara dengan kalimat yang pendek, sederhana, dan mudah dipahami oleh anak.

j. Ajukan pertanyaan terbuka dan merangsang anak untuk berpikir atau menemukan jawaban sendiri.Berikan kesempatan pada anak untuk menyampaikan sesuatu pada orangtua dengan memberinya pertanyaan yang memungkinkan anak menjawab lebih bebas atau terbuka. Jika orang tua ingin mengetahui alasan anak berbuat sesuatu, sebaiknya hindari pertanyaan dengan jawaban tertutup, misalnya "ya" dan "tidak". Contoh: "Tadi di sekolah belajar enggak?" Anak tentu akan memberikan jawaban ya atau tidak. Sebaiknya kalimatnya, "Tadi diajak belajar apa saja sama $\mathrm{Bu}$ Guru?". Anak tentu akan menjawab dengan kalimat yang lebih panjang dan bervariasi untuk menceritakan pengalamannya.

k. Berikan teladan. Pada saat anak mengalami peristiwa tertentu, seperti sakit, sedih, kecewa, senang, takut, dan sebagainya, sebaiknya orangtua memahami perasaan anak dengan menanyakan apa yang sedang dirasakan sehingga anak merasa aman dan dipahami. 
1. Jadilah pendengar yang baik Dengarkan dengan penuh perhatian ketika anak menyampaikan sesuatu. Dengarkan sampai si anak selesai berbicara atau menceritakan permasalahannya. Hindari memotong pembicaraan anak. Tinggalkan aktivitas yang kita lakukan supaya anak merasa benarbenar mendapatkan perhatian kita.

m. Beri tanggapan yang benar.Berikan kebebasan pada anak untuk mengungkapkan perasannya. Bila diperlukan, ulangi cerita anak untuk menyamakan pengertian. Berikan tanggapan yang tepat agar anak merasa nyaman dan merasa dihargai.

n. Gunakan nada suara yang wajar pada saat kita bicara pada anak. Gunakan intonasi dan nada suara yang wajar dan sesuai dengan situasi. Ketika menegur anak pada saat melakukan kesalahan, tidak perlu membentak atau menggunakan nada suara yang tinggi.

o. Gunakan kata-kata 'emas' ketika berbicara dengan siapa pun, khususnya kepada anak, sepertitolong, maaf, terimakasih, permisi, dan sebagainya. Dengan demikian, anak akan terbiasa berbicara dengan sopan dan menghargai orang lain sejak usia dini.

\section{E. Penutup}

Anak memperoleh dan mempelajari bahasa pertama sekali dari lingkungannya. Lingkungan yang pertama tentu saja keluarga atau ayah dan ibunya. Saat anak sudah mulai sekolah, peran guru juga sangat penting dalam membentuk bahasa anak. Bahasa tersebut digunakan anak sebagai alat sosialisasi dan mengekspresikan perasaanya dengan kosakata yang dikuasainya.

Bahasa membawa pengaruh terhadap perkembangan sosial, emosional, fisik, dan kognitif anak.Peran orang tua dan guru sangat penting dalam membangun bahasa yang komunikatif untuk mengatasi semua pengaruh perkembangan tersebut. Sudah sepatutnya orangtua dan guru memberi perhatian yang khusus terhadap perkembangan bahasa anak sejak usia dini karena bahasa memiliki peran yang penting dalam membentuk karakter anak. Anak yang bisa menyampaikan semua keinginan maupun ekspresinya dengan menggunakan 
bahasa yang baik tentu memiliki karakter yang baik pula. Namun, jika anak selalu diperlakukan tidak baik, selalu mendengar orangtuanya berbicara yang kasar, tentu akan berpengaruh terhadap perkembangan karakternya, seperti suka berbicara kasar, tidak menghargai orang lain, dan sebagainya. Oleh karena itu, orangtua dan guru harus memberikan perhatian kepada perkembangan bahasa anak dengan selalu membangun bahasa yang komunikatif saat berkomikasi dengan anak.

\section{Daftar Bacaan}

Alwasilah, A. Chaedar. 1990. Sosilogi Bahasa. Bandung: Angkasa.

Aziez. 2015. Pengajaran Bahasa Komunikatif Teori dan Praktik. Yogyakarta: Pustaka Pelajar.

Departemen Pendidikan Nasional. 2004. Metode Khusus Pengembangan Kemampuan Berbahasa. Jakarta: Depdiknas.

Detty, Noviyanti dkk. 2017. "Pendekatan Komunikatif Interaktif untuk Meningkatkan Kosakata Anak Usia Dini”. Dalam Jurnal Cakrawala Dinivolume 8, nomor 1. Bandung: UPI.

Dhieni, N., dkk. 2006. Metode Pengembangan Bahasa. Jakarta: Universitas Terbuka

Keraf, Gorys. 1980. Komposisi. Ende Flores: Nusa Indah.

Kusnandar. 2012. Langkah Mudah Penelitian Tindakan Kelas sebagai Pengembangan Profesi Guru. Jakarta: Raja Grafindo Persada.

Majid, A. 2013. Strategi Pembelajaran. Bandung: Remaja Rosdakarya.

Muhibbin, Syah. 2003. Psikologi Belajar. Jakarta: Raja Grafindo Persada.

Suhartono. 2005. Pengembangan Ketrampilan Bicara Anak Usia Dini. Jakarta: Departemen Pendidikan Nasional.

Syaiful Bahri Djamarah, 2002. Psikologi Belajar. Jakarta: Rineka Cipta.

Tim Penyusun Kamus Pusat Pembinaaan dan Pengembangan Bahasa. 2004. Kamus Besar Bahasa Indonesia Edisi IV. Jakarta: Balai Pustaka. 